\title{
Giant Germ Tumor Retroperitoneal Lymphadenopathy Encapsulating the Infrarenal Aorta and Inferior Vena Cava: Case Report
}

\author{
Róbert Novotnýa ${ }^{a}$, Libor Janoušek ${ }^{a, c}$, Květoslav Lipara, Jaroslav Chlupáčca,b, \\ Jakub Křístek ${ }^{a, d}$, Michal Kudla ${ }^{a, b}$, Jiří Froněk ${ }^{a, b, c}$
}

a Transplant Surgery Department, Institute for Clinical and Experimental Medicine, Prague

${ }^{b}$ First Faculty of Medicine, Charles University, Prague

' Second Faculty of Medicine, Charles University, Prague

'Department of Anatomy, Second Faculty of Medicine, Charles University, Prague

\section{ARTICLE INFO}

Article history:

Submitted: 27. 8. 2019

Accepted: 16. 1. 2020

Available online: 22. 10. 2020

\section{Klíčová slova:}

Germinální

Lymfadenopatie

Metastázy

Nádor

Resekce

Retroperitoneální

Teratom
SOUHRN

Úvod: Nádor z testikulárních germinálních buněk (GCT) je nejčastějším maligním solidním nádorem u mužů s nejvyšší incidencí mezi 15-45 lety. GCT prokázal rostoucí výskyt za posledních 30 let.

Metoda: Operace byla provedena přes střední laparotomii. $V$ břiše byla nalezena masivní retroperitoneální lymfadenopatie (RL). Intrarenální aorta (IA) a dolní dutá žila (IVC) byly pečlivě vypreparovány a zcela zbaveny RL. Část levé renální žíly (LRV) byla suspektně infiltrovaná RL. Proto jsme provedli částečnou resekci LRV. Zbytková LRV byla krátká a reanastomóza na IVC nebyla možná. LRV byla reanastomozována na splenickou žílu. Vzhledem $k$ velké velikosti resekovaného RL v kombinaci s blízkým kontaktem s IA a IVC byly do dutiny břišní vloženy chirurgické roušky pro vysoké riziko pooperačního krvácení. "Second look" byl proveden 24 hodin po zákroku a střední laparotomie byla uzavřena standardním způsobem.

Výsledky: Pooperační období proběhlo bez komplikací. Pacient byl propuštěn osmý pooperační den s dobrými renálními funkcemi a dobrou perfuzí levé ledviny dle Dopplerovy ultrasonografie.

Závěr: U pacientů s GCT a velkými retroperitoneálními masami je nutný multidisciplinární př́stup kombinující chemoterapii a chirurgický zákrok, aby se významně zvýšil léčebný úspěch.

(c) 2020, ČKS.
Keywords:

Germinal

Lymphadenopathy

Metastasis

Resection

Retroperitoneal

Teratoma

Tumour

\section{ABSTRACT}

Introduction: Testicular germ cell tumour (GCT) is the most common malignant solid tumour among Caucasian men with the highest incidence between 15-45 years. GCT had shown an increasing incidence in the past 30 years.

Method: The procedure was performed through the midline laparotomy. Massive retroperitoneal lymphadenopathy (RL) was found in the abdomen. The infrarenal aorta (IA) and inferior vena cava (IVC) were carefully dissected and entirely freed from the RL. Part of the left renal vein (LRV) showed suspicious infiltration by the RL. Therefore we performed a partial LRV resection. The residual LRV was short, the reanastomosing to the IVC was not possible. We reanastomosed the residual LRV to the splenic vein. Due to the large size of the resected RL combined with a close encounter with IA and IVC, surgical swabs were placed into the abdomen for high risk of postoperative bleeding. The second look was performed 24 hours after the procedure, and the midline laparotomy was closed in a standard manner.

Results: Postoperative period was uneventful. The patient was discharged on the 8th postoperative day with good renal functions and good left kidney perfusion and drainage on Doppler's ultrasonography.

Conclusion: A multidisciplinary approach combining chemotherapy and surgical intervention is needed in patients with GCT and large retroperitoneal masses in order to significantly increase the curative success. 


\section{Introduction}

Testicular germ cell tumour (GCT) is the most common malignant solid tumour among Caucasian men with the highest incidence between 15-45 years. GCT had shown an increasing incidence in the past 30 years. ${ }^{1}$ Based on histopathology GCT are divided into two basic categories: seminomas (SGCT) and non-seminomas (NGCT). They both originate from germ cell neoplasia in situ. ${ }^{2}$ NGCT can be further divided based on their variable histological architecture into embryonal carcinoma, teratoma, choriocarcinoma, tumour, and yolk sac. NGCT account for $23.7 \%$ of all GCT. ${ }^{2}$ NGCT are showing undaughterly more metastatic behaviour than SGCT with a significantly worse prognosis when comparing both tumours at the same stage. $^{3}$

\section{Case presentation}

We are presenting a case of a 28-year-old male patient after orchiectomy in May 2018 for a GCT non-seminoma with a prevalence of embryonal carcinoma (pT2-3, cN3, M1a, S2) followed by four cycles of cisplatin and etoposide chemotherapy with partial regression of lung metastasis. During the preoperative screening, a computed tomography angiography (CTA) of the abdomen was performed. This showed left kidney hydronephrosis with ureter compression caused by massive retroperitoneal lymphadenopathy ( $\mathrm{RL}$ ) encapsulating the infrarenal aorta (IA) and inferior vena cava (IVC) (Fig. 1). No invasion of the RL into the SA and IVC was visible on the CTA. The patient underwent $\mathrm{JJ}$ stent insertion into the left ureter in order to preserve physiological kidney function. PET scan of the abdomen showed the metabolic activity of the RL (Fig. 2). The patient was referred to our centre for the resection of the retroperitoneal lymphadenopathy from the larger vessels.

The procedure was performed through the midline laparotomy. A massive $20 \times 17 \mathrm{~cm}$ RL was found in the abdomen confirming the CTA images (Fig. 3A). The RL was avascular based on the CTA and was carefully resected in two pieces (Fig. 3B, 3C). The SA and IVC were carefully
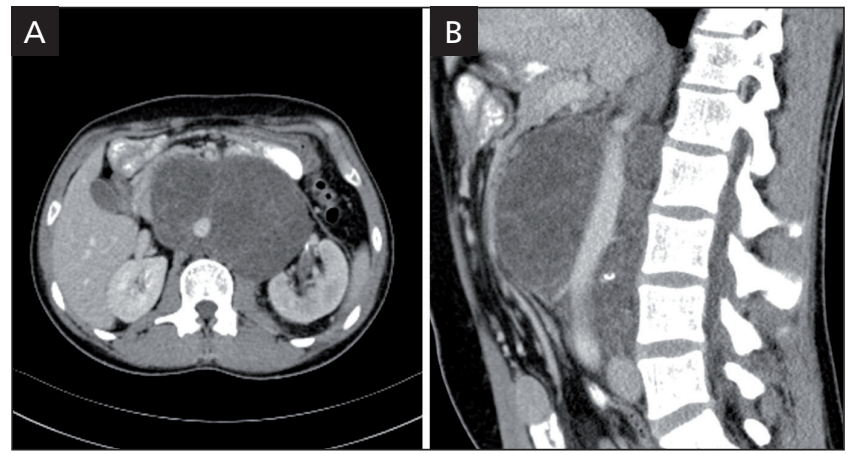

Fig. 1 - Computed tomography angiography of the abdomen revealing retroperitoneal lymphadenopathy encapsulating subrenal aorta and inferior vena cava. (A) Cross-section of the abdomen with massive retroperitoneal lymphadenopathy encapsulating inferior vena cava. (B) Transverse section of the abdomen with massive retroperitoneal lymphadenopathy encapsulating subrenal aorta.

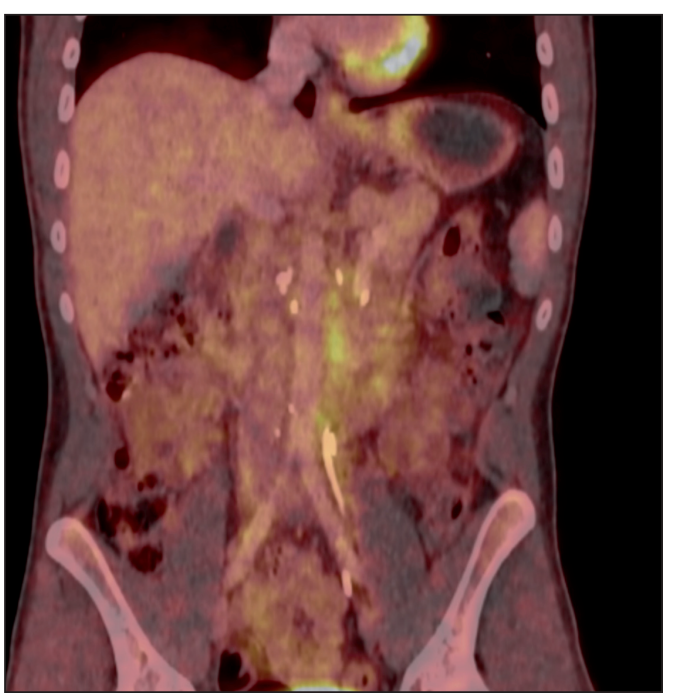

Fig. 2 - PET scan of the abdomen with massive retroperitoneal lymphadenopathy encapsulating I subrenal aorta and inferior vena cava.

dissected and entirely freed from the RL (Fig. 3D). Part of the left renal vein (LRV) showed suspicious infiltration by the RL. Therefore we performed a partial LRV resection. The residual LRV was short, the reanastomosing to the IVC was not possible. Due to the tumorous infiltration of the retroperitoneum, we wanted to avoid a prosthetic graft reconstruction. Therefore, we re-anastomosed the residual LRV to the splenic vein using end-to-side anastomosis
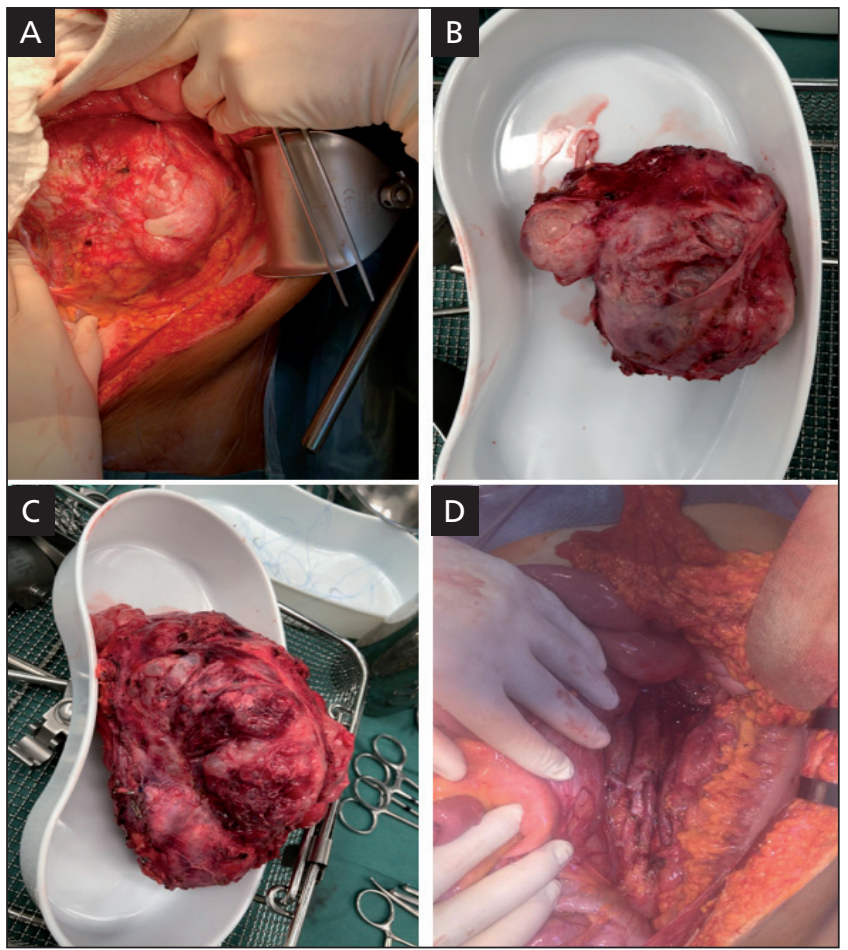

Fig. 3. - Perioperative finding. (A) Massive retroperitoneal lymphadenopathy encapsulating large vessels. (B) Resected right part of the retroperitoneal lymphadenopathy encapsulating the subrenal aorta. (C) Resected left part of the retroperitoneal lymphadenopathy encapsulating the inferior vena cava. (D) Dissected subrenal aorta and inferior vena cava, complete removal of retroperitoneal lymphadenopathy encapsulating the large vessels. 
with Prolene 6/0. Due to the large size of the resected $\mathrm{RL}$ combined with a close encounter with SA and IVC, surgical swabs were placed into the abdomen for high risk of postoperative bleeding. The second look was performed 24 hours after the procedure, and the midline laparotomy was closed in a standard manner.

Postoperative period was uneventful, and the patient was discharged on the 8th postoperative day with good renal functions and good left kidney perfusion and drainage on Doppler's ultrasonography. The patient was discharged on a prophylactic dose of LMWH for one month. $\mathrm{RL}$ histology revealed retroperitoneal teratoma, most probably a metastasis of a germ tumour.

Currently, we have 4-month follow-up on the patient with no $\mathrm{RL}$ reoccurrence in the retroperitoneum.

\section{Discussion}

CGT is unique in their clinical presentation and response to chemotherapy. This is due to their origin in primordial germ cells. ${ }^{4}$ The cure rate of GCT in the modern era of medicine can reach up to $80 \% .{ }^{5}$ However, patients with relapse of GCT with ineffective chemotherapy have significantly shortened their life span by up to 35 years. This occurs in $40-80 \%$ of patients with CGT relapse. ${ }^{3}$

NCGT are predominantly mixed tumours with frequently found teratoma at their metastatic sites. ${ }^{2,6}$ Papers by BS Carver et al. and M. Catherine et al. showed that the incidence of teratoma in the residual metastatic $\mathrm{RL}$ ranges between 15-23\%., ${ }^{7,8}$ Patients presented with metastatic disease require combined treatment of chemotherapy and surgery. The decision whether to perform RL resection is planned purely based on diagnostic modalities. $\mathrm{RL}$ resection is an essential part of the management of patients with NGCT especially when it possesses a high risk of large vessels compression or infiltration, organ compression. Also, it allows us to examine the remaining histological elements in the metastatic mass after chemotherapy. ${ }^{6}$

Furthermore, the presence of teratoma in the residual RL after chemotherapy is hazardous as its behaviour is very unpredictable. It may remain dormant or grow slowly. In some cases, it can show a rapid growth leading to local invasion. Furthermore, approximately $<10 \%$ of teratomas in residual RL may undergo malignant somatic transformation to a malignancy such as adenocarcinoma or primitive neuroectodermal tumour which are associated with a very poor prognosis. ${ }^{9}$

\section{Conclusion}

NCGT require a multidisciplinary approach, the combination of chemotherapy and surgical intervention especially in patients with large retroperitoneal masses. If no NCGT relapse occurs after the chemotherapy, the patient's survival rate is very good.

\section{Acknowledgements}

The author would like to thank to doc. MUDr. Jiří Froněk, Ph.D., FRCS and MUDr. Jaroslav Chlupáč, Ph.D., Transplant Surgery Department, Institute for Clinical and Experimental Medicine, Prague, the Czech Republic for providing their opinion on this case.

\section{Conflict of interest}

The authors declare that there is no conflict of interests regarding the publication of this article.

\section{Funding}

This research received no specific grant from any funding agency in the public, commercial, or not-for-profit sectors.

\section{Informed consent}

Written informed consent was obtained from the patient for publication of this case report and accompanying images. A copy of the written consent is available for review by the Editor-in-Chief of this journal.

\section{References}

1. Miyai K, Ito K, Nakanishi K, Tsuda H. Seminoma component of mixed testicular germ cell tumour shows a higher incidence of loss of heterozygosity than pure-type seminoma. Hum Pathol 2019;84:71-80.

2. Stang A, Rusner C, Trabert B, et al. Incidence of testicular tumor subtypes according to the updated WHO classification, North Rhine-Westphalia, Germany, 2008-2013. Andrology 2019;7:402-407.

3. Adra N, Abonour R, Althouse SK, et al. High-dose chemotherapy and autologous peripheral-blood stem-cell transplantation for relapsed metastatic germ cell tumors: the Indiana University experience. J Clin Oncol 2017;35:1096-1102.

4. Cheng L, Albers P, Berney DM, et al. Testicular cancer. Nat Rev Dis Primers 2018;4:29.

5. Albany C, Adra N, Snavely AC, et al. Multidisciplinary clinic approach improves overall survival outcomes of patients with metastatic germ-cell tumors. Ann Oncol 2018;29:341-346.

6. Dowling CM, Assel M, Musser JE, et al. Clinical Outcome of Retroperitoneal Lymph Node Dissection after Chemotherapy in Patients with Pure Embryonal Carcinoma in the Orchiectomy Specimen. Urology 2018;114:133-138.

7. Dowling CM, Assel M, Musser JE, et al. Clinical Outcome of Retroperitoneal Lymph Node Dissection after Chemotherapy in Patients with Pure Embryonal Carcinoma in the Orchiectomy Specimen. Urology 2018;114:133-138.

8. Carver BS, Bianco FJ Jr, Shayegan B, et al. Predicting teratoma in the retroperitoneum in men undergoing post-chemotherapy retro-peritoneal lymph node dissection. J Urol 2006;176:100103, discussion 103-104.

9. Singh $P$, Yadav S, Mahapatra S, Seth A. Outcomes following retroperitoneal lymph node dissection in postchemotherapy residual masses in advanced testicular germ cell tumors. Indian J Urol 2016;32:40-44. 